\title{
CROP TOLERANCE TRIALS WITH TCA
}

\author{
By J. S. YEATES, Massey Agricultural College
}

THE object was to test the tolerance of various crop seeds to TCA applied under field conditions under the particular conditions of soil and rainfall at the College.

The soil was a silt loam, containing a fair amount of organic matter.

\section{PLAN OF EXPERIMENT}

Eighteen plots were laid out, each $13 \mathrm{ft}$. by $9 \mathrm{ft}$. 4 in. The plots were in 3 rows separated by paths $2 \mathrm{ft}$. wide. No crop seeds were sown nearer than 1 in. from the margin of the adjacent plot. The soil was worked down to make a fine seed-bed.

\section{TCA APPLICATION}

Treatments were:--

\begin{tabular}{|c|c|c|}
\hline \\
\hline \multicolumn{3}{|c|}{$\begin{array}{l}\text { Control } \\
\text { 5lb. TCA/acre. }\end{array}$} \\
\hline $201 \mathrm{~b}$. & " & „, \\
\hline $351 \mathrm{lb}$. & , & " \\
\hline 501b. & " & " \\
\hline $751 \mathrm{~b}$. & , & \\
\hline $1001 b$. & ", & 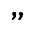 \\
\hline $\begin{array}{l}2001 \mathrm{~b} . \\
\text { Con }\end{array}$ & & \\
\hline
\end{tabular}

Application of the TCA was effected by dissolving the appropriate weight for each plot in 1.32 gallons of water and applying it through a watering-can fitted with a rose. Two randomised plots were given each treatment. Date of application was 28 February 1953.

SOWING OF CROP SEEDS

The following crop seeds were sown on 3 and 4 March:Broad beans-Cole's Early Dwarf.

Barley-College.

Chou moellier.

Red clover.

Swede-Superlative.

Onion-Pukekohe Long Keeper.

Mangold-Prizewinner.

Turnip.

Oats-Algerian.

Peas-Greenfeast.

One row of each of the crops was sown across each plot. In order to give a better idea of germination percentage an equal number, by 111 
count, of the larger seeds was sown in each row, and an equal weight of onion, for instance, in each row of onion.

\section{RAINFALL AND SOIL MOISTURE}

At the commencement of the experiment 4 soil samples taken from a depth of 3in. showed an average of 16.62 per cent. moisture.

During the week 28 February to 6 March in which the plots were laid down and for the following 5 days the total rainfall was 0.07in. The totals for each month during which the trial was observed were:-

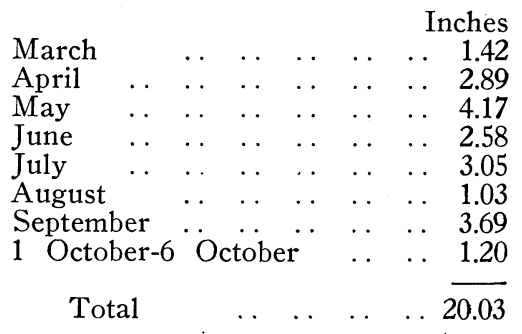

SUMMARY OF RESULTS (May, 1953)

Broad beans: Germination little affected by any dosage of TCA, but with 501b. and upwards, foliage distorted-leaves twisted and tight in half-expanded state. Brittle. At 2001b. growth very markedly retarded.

Barley: Numbers emerging in various plots so erratic that no conclusion can be reached. However, plants weak and small in 751b. plots and upwards. No $\left\{\begin{array}{c}\text { emergence } \\ \text { germination }\end{array}\right\}$ with 2001b. treatment.

Chou moellier: No detrimental effect in plots of 501b. and less. At $751 \mathrm{~b}$. there was a retardation of growth, and at 100 and $2001 \mathrm{~b}$. the foliage yellowed.

Red clover: Normal growth up to and including 501b. Retarded growth with 751b., 1001b., and 2001b.

Swede: Under all applications this crop appeared to follow normal growth without any obvious detrimental effect appearing.

Onion: Only at 2001b. was the crop much affected. At this rate of treatment emergence was reduced and there was evidence of mortality occurring in emerged plants.

Mangold: Growth retarded in 751b. and 1001b. plots, and germination was poor, in addition, in the 2001b. plots.

Turnip: Only at 2001b. was an effect apparent. This involved a yellowing of the foliage.

Oats: As with barley, the numbers emerging in the various plants was very erratic and no conclusion is possible. At the two highest concentrations the plants were invariably small and lacked vigorous appearance. In contrast to barley, germination was not prevented by the 2001b.

Peas: Although emergence was not apparently affected, foliage abnormalities appeared in treatments from 351b. upwards with gross distortion at 2001b. Distortion similar in nature to that of broad bean. 
ADDITIONAL OBSERVATIONS (6 October, 1953)

$2001 \mathrm{~b}$. rate: The only surviving plants were one plant each of chou moellier, swede, mangold, and some turnips, the last-named by then $7 \mathrm{ft}$. high. There was an 80 per cent. soil cover of weeds, including Spergula arvensis, Crepis capillaris, Coronopus didymus, Juncus bufonius, Gnaphalium, and Sonchus oleraceus.

1001b. rate: One broad bean plant survived, sparse chou moellier up to $2 \mathrm{ft}$., the mangolds were $1 \mathrm{ft}$. 3in. high with bulbs 3in. to 4in. diameter, and turnips were $3 \mathrm{ft}$. 6in. high. The weeds were similar to those in the 2001b. treatment.

751b. rate: There was one broad bean; a few mangolds with lin. bulbs, and sparse turnips. Weeds as above.

501b. rate: There were no broad beans; a few plants of barley $3 \mathrm{ft}$. high and heading; mangolds with bulbs $2 \mathrm{I} / 2 \mathrm{in}$. diameter; turnips $3 \mathrm{ft}$. $6 \mathrm{in}$. high, and sparse oats $2 \mathrm{ft}$. 6in. high. Weeds as above.

$35 \mathrm{lb}$. rate: Broad beans $3 \mathrm{ft}$. 6in. high; chou moellier $2 \mathrm{ft}$; mangolds $2 \mathrm{ft}$. high; oats $2 \mathrm{ft}$. 6in. high; swedes $3 \mathrm{ft}$. 6in. high. Additional weeds included grass weeds.

201b. rate: Broad beans $3 \mathrm{ft}$. 6in. with pods $4 \mathrm{r} / \mathrm{2}$ in. long, chou moellier $3 \mathrm{ft}$. high, good, a few oats to $2 \mathrm{ft}$. high. No grass weeds.

101b. rate: Beans 2ft. 6in. high, pods 41/2in. long; barley $2 \mathrm{ft}$. 6in. high; mangolds sparse, $2 \mathrm{~T} / 2 \mathrm{in}$. bulbs; turnips $3 \mathrm{ft}$. $6 \mathrm{in}$. high; oats $2 \mathrm{ft}$. $6 \mathrm{in}$. high. Grass weeds included prairie grass.

5lb. rate: Beans $3 \mathrm{ft}$. 6in., pods 41/2in. long, chou moellier $4 \mathrm{ft}$; ; oats $2 \mathrm{ft}$. 6in.; sparse red clover; swedes $3 \mathrm{ft}$. 6in.; turnips $4 \mathrm{ft}$; mangolds $1 \mathrm{ft}$. high. Weeds good coverage, species as in other plots.

Control: Beans $3 \mathrm{ft}$. 6in. high, pods 5in. long; chou moellier $2 \mathrm{ft}$. high; barley $2 \mathrm{ft}$. 6in. high; red clover sparse; turnip $2 \mathrm{ft}$. 3in. high. Weeds were: Poa annua, Glyceria, and other weeds mentioned under the 2001b. rate.

Second sowing: A second sowing of the same varieties of crops was made at the end of August, 6 months from time of treatment. Notes made on 6 October showed no apparent remaining effects from the use of TCA on any of the plots.

\section{CONCLUSIONS}

The sowings having been made out of season, in autumn, did not give a fair indication as to the ultimate growth of the crops. Onions and peas, for instance, did not survive to October in any plot. Because of erratic final results and also bird damage after sowing no statistical treatment of the results was possible.

The outstanding feature was the resistance of the different crucifers to TCA even at dosages of $1001 \mathrm{~b}$. per acre. The mangold also showed considerable resistance to $1001 \mathrm{~b}$. per acre. The leguminous crops showed definitely less resistance, a maximum dosage of 35lb. per acre being indicated as safe. Although onions showed high resistance in the first 2 months, their failure to survive to October in any plot leaves their position indefinite.

On the basis of these results an upper limit of 501b. per acre of TCA would appear to be wise where crucifers are to be planted under conditions similar to those in the trial.

Thanks are due to Messrs. Ivon Watkins, Ltd., for financial help in these trials. 